\title{
DIGITALISASI MANAJEMEN PENDIDIKAN ISLAM DAN EKONOMI SYARIAH DI PERGURUAN TINGGI
}

\author{
Alan Suud Maadi \\ Institut Agama Islam (IAI) Al-Khairat Pamekasan \\ alansuudmaadi@yahoo.com
}

\begin{abstract}
Management of Islamic education and Sharia Economics has experienced rapid development and progress. The digital era brings significant changes to both dimensions of science in various aspects of life. In addition, Islamic Education Management and Sharia Economics is a national subsystem in direct contact with the pattern of community life. So it is necessary to get around and find solutions by looking at the various opportunities and challenges in printing golden generation is multidimensional. This paper will describe the strategies, opportunities and challenges of Islamic education management and Islamic economics in universities in the digital era with a library research approach. Furthermore, in this paper will also describe the condition of the global level to provide an overview of the Indonesian context. the results of this study that the opportunities and challenges of universities in internal and external aspects. The strategy by improving the scientific culture of digital learning trends and virtual based services.

Keyword: Management of Islamic Education, Sharia Economics, Digital Era.
\end{abstract}

\begin{abstract}
Abstrak
Manajemen pendidikan Islam dan Ekonomi syariah telah mengalami perkembangan dan kemajuan yang sangat pesat. Era digital membawa perubahan yang signifikan kepada kedua dimensi keilmuan tersebut dalam berbagai aspek kehidupan. Selain itu Manajemen Pendidikan Islam dan Ekonomi Syariah merupakan subsistem nasional yang bersentuhan langsung dengan pola kehidupan masyarakat. Sehingga perlu menyiasati dan mencari solusi dengan mencermati berbagai peluang dan tantangan dalam mencetak generasi emas yang multidimensi. Tulisan ini akan menguraikan strategi, peluang dan tantangan manajemen pendidikan islam dan ekonomi syariah di perguruan tinggi di era digital dengan pendekatan library research. Selanjutnya dalam penulisan ini juga akan menguraikan kondisi tataran global untuk memberikan gambaran pada konteks Indonesia. Hasil dari penelitian ini bahwa peluang dan tantangan
\end{abstract}


perguruan tinggi dalam aspek internal maupun eksternal. Adapun strateginya dengan meningkatkan budaya keilmuan trend pembelajaran digital dan pelayanan berbasis virtual.

Kata Kunci: Manajemen Pendidikan Islam, Ekonomi Syariah, Era Digital.

\section{Pendahuluan}

Pengaruh digitalisasi atau yang biasa disebut dengan zaman milenial sudah merambat keberbagai belahan dunia. Perkembangan teknolgi menyebabakan percepatan pertukaran budaya antar bangsa. Selain itu kemampuan memproduksi alat-alat teknologi menjadi variable untuk mengukur kemajuan peradaban di zaman milenial, merupakan salah satu penyebab berubahnya paradigma berpikir manusia dan pergeseran budaya serta semakin berdimenasinya sistem manajerial tatanan pengelolaan sebuah negara. Tuntutan kehidupan yang serba instan, gaya hidup yang milenial dan majunya peradaban dunia dapat dengan mudah di akses melalui teknolgi keberbagai belahan dunia. Era digital bisa dimaknai sebagai suatu keadaan di mana penggunaan perangkat komunikasi dan informasi berbasis digital (internet). ${ }^{1}$ Menurut Dorojatun Kuntjoro Jakti bahwa globalisasi setidaknya disebabkan dari revolusi tiga $\mathrm{T}$ (Transportasi, Telekomunikasi, dan Torism). Hal ini dapat dibuktikan dengan perkembangan teknologi transportasi yang melahirkan era the end of geography, dengan perkembangan teknologi komunikasi akan melahirkan era the end of timelines secara relatif, dan revolusi turis dapat berakibat meningkatnya arus pertukaran manusia yang dapat memungkinkan terkikisnya hambatan-hambatan sosial-politik-kultural. ${ }^{2}$

Internet dengan mudah diakses diberbagai belahan dunia. Sehingga ekspansi keilmuan khususnya dalam penulisan ini yaitu manajemen pendidikan islam, ekonomi syariah dan perbankan syariah diperlukan strategi dan solusi untuk melihat peluang dan tantangan zaman yang dapat berkontribusi kepada public. Persaingan di era digitalisasi ini sedikit banyak dipengaruhi oleh sistem ekonomi yang pernah ada dan semakin

\footnotetext{
${ }^{1}$ Menurut Randall dan Latulipe, internet merupakan singkatan dari interconnection networking, yang berarti a global network of computer networks. Makna lainnya, internet merupakan kumpulan luas dari jaringan komputer yang saling terhubung di seluruh dunia, mulai dari komputer kecil (personal computer) di rumah-rumah sampai komputer besar di perusahaan-perusahaan. Fungsi internet adalah sebagai media komunikasi dan pertukaran informasi. Lihat Fandy Tjiptino dan Totok Budi Santoso, Strategi Riset Lewat Internet, (Yogyakarta: Andi, 2010), 2

${ }^{2}$ Emil Salim, dkk., Manajemen dalam Era Globalisasi, (Jakarta: PT. Elex Media Komputindo, 1997), 153-154.
} 
berkembang di dunia ini yaitu sistem ekonomi sosialis, sistem ekonomi kapitalis dan sistem ekonomi islam.

Manajemen pendidikan Islam, ekonomi syariah dan perbankan syariah yang merupakan dinamika dari aktualiasi keilmuan yang masuk pada sistem tatanan kehidupan masyarakat dan negara secara otomatis dituntut membentuk sebuah perubahan dan inovasi. Inovasi yang dimaksud adalah menciptakan terobosan baru yang berbasis digital.Inovasi dengan strategi-strategi yang perlu dipersiapkan dan diimplementasikan dengan teori dan fakta dimana dalam hal ini penulis akan membagikan kepada tiga ranah pembahasan. Pertama dalam ruang lingkup manajemen pendidikan islam. Kedua ekonomi syariah. Ketiga perbankan syariah. Ketiganya akan diuraikan strategi, peluang dan tantangan untuk menghasilkan sebuah ulasan yang relevan diimplementasikan di era digital. Ketiga cakrawala keilmuan tersebut membutuhkan sebuah perencanaan, pengorganisasian, pengawasan dan keterampilan yang mumpuni sesuai dengan digitalisasi tekhnologi. Sehingga dengan merangsang dan mengaplikasikannya dengan baik dan sistematis manajemen pendidikan islam, ekonomi syariah dan perbankan syariah yang mampu tampil dengan segala sumberdaya yang dimiliki serta mempunyai keunggulan atau kompetensi knowledge, skill dan personality.

Sebagai aktualisasi keilmuan, harus mampu menyesuaikan dan beradaptasi agar tidak terlupakan dari model keilmuan lainnya. Manajemen pendidikan islam dengan segala kelebihannya diharapkan dapat memanfaatkan digitalisasi era sebagai pioner pendidikan yang bermutu. Kemudian ekonomi syariah dengan semua kemajuan tekhnologi yang dimanfaatkan mampu memberikan jawaban kerisaukan akan pentingnya bermualah dengan baik. Adapun perbankan syariah yang perkembangannya sangat signifikan beberapa tahun ini dengan keyakinan dan harapan besar dapat memberikan solusi tidak hanya dalam aspek ekonomi saja tetapi juga mengayomi masyarakat dalam terobosan-terobosan kontrak akad yang ditawarkan.

\section{Analisis Peluang dan Tantangan Institusi Perguruan Tinggi di Zaman Milenial Manajemen Pendidikan Islam}

Banyak peluang dan kesempatan emas diera digitalisasi ini yang selalu berkembang maju. Hal tersebut semakin memacu kepada lembaga pendidikan islam untuk dijadikan modal dan kekuatan dalam membuktikan eksistensi lembaga 
pendidikan islam dalam mencapai kajayaan perdabaan islam seperti goldenageof civilization. Sementara tantangan selama ini yang telah wujud sebagai power untuk mengeksplorasi keunggulan-keunggulan lembaga pendidikan islam yang selama ini potensi dan aksinya selalu dipandang sebelah mata oleh masyarakat.

Era digital memberikan dampak yang sangat signifikan terhadap kehidupan manusia yang tidak bisa dilepaskan dari keberadaan teknologi dan komunikasi.Komplesitas kehidupan digital menuntut manusia untuk merubah dengan sistem yang lebih fektif dan efesien. Kondisi ini juga meluas kepada peluang dan tantangan Manajemen Pendidikan Islam. Perkembangan digitalisasi umumnya berpusat pada kemajuan IPTEK terutama dalam kamjuan tekhnologi dan komunikasi.Wujudnya perdagangan bebas di pasar global (market global), mudahnya bekerjasama antar regional dan international dengan inovasi-inovasi produk yang diciptakan.

Dengan kondisi tersebut, pendidikan islam dituntut untuk melakukan inovasi dan perbedaan metode, kurikulum dan sarana prasarana. Perubahan wajah pendidikan dari semua aspek harus digalakkan seiring dengan konteks digitalisasi. Hal tersebut tidak terlepas dari manajemen atau pengelolaan mulai dari tingkat pusat hingga tingkat daerah dengan menciptakan inovasi yang relevan dan terintegrasi.

Beberapa aktualisasi ilmu pendidikan islam yang kongkrit telah diciptakan oleh pemerintah pusat dan daerah dengan merubah pola manajemen pendidikan standarisasi ujian nasional berbasis komputer (based of cumputer)di sekolah dasar hingga perguruan tinggi, sistem pengurusan dari daerah ke pusat dengan singkronisasi berbasis internet dan semakin integrasinya perguruan tinggi negeri dan swasta yang dibuktikan dengan satuan pangkalan data perguruan tinggi di bawah kemenristek dikti dan kemenag. Bahkan beberapa tahun sebelumnya pemerintah melalui kemendikbud membuka kelas international di tingkat sekolah dasar hingga menegah atas dan dilanjutkan di perguruan tinggi negeri maupun swasta dengan maksud untuk meningkatkan pola kerjasama antar institusi dan negara dalam meningkatkan mutu pendidikan menuju golden generation.

Adapun Tantangan-Tantangan yang dihadapi oleh pendidikan Islam adakalanya berbentuk tantangan internal dan eksternal. Menurut Arifi, tantangan internal yang selalu dihadapi oleh pendidikan islam yaitu orientasi dan tujuan pendidikan, pengelolaan (management), dan hasil (output). Tilaar menyebutkan tantangan utama 
pendidikan adalah kualitas. ${ }^{3}$ Sedangkan tantangan eksternal yang muncul adanya pertarungan ideologi-ideologi besar dunia. ${ }^{4}$

Selain tantangan diatas di era digital ini, yang lebih urgen dan harus dihadapai oleh lembaga pendidikan islam adalah tantangan yang meliputi aspek kelembagaan dan penguatan konteks materi pendidikan. Karena pengelolaan manajemen pendidikan islam terkontaminasi kepada cepatnya perubahan digitalisasi di setiap waktu yang diingatkan kepada dua kategori pendidikan yang masuk ke permukaan pendidikan yang dikendalikan oleh pasar (market driven education) dan pendidikan yang berorientasi kepada penciptaan pasar (market creation based education). Sehingga bagaimana pengelolaan (manajerial) pendidikan islam dapat direncanakan, dievaluasi dan memproduksi kurikulum, metode pembelajaran, desentralisasi pendidikan dan otonomi pendidikan dengan merelevankan kepada kondisi kondisi dunia global. Kemudian rendahnya daya saing lulusan lembaga pendidikan islam, kurikulum yang overload dan sarana prasaranan yang belum bisa terpenuhi untuk berdaya saing tinggi menjadi problematika penting untuk manajemen pengelolaan pendidikan tinggi agama islam negeri dan swasta.

\section{Ekonomi Syariah}

Salah satu problematika mendasar yang sering dihadapi oleh akademisi dan praktisi ekonomi islam yaitu minimnya sumber daya manusia yang mampu memahami secara komprehensif dalam mengurus dan mengelola lembaga keuangan syariah yang berdampak kepada kurangnya kualitas pelayanan terhadap nasabah. Sepertimana dalam penelitian yang dilakukan oleh Suherman ${ }^{5}$ merekomendasikan perlunya dilakukan peningkatan kualitas pelayanan. Karena kualitas pelayanan akan berpengaruh terhadap peningkatan jumlah nasabah. Kurang tepat jika praktisi ekonomi syariah khususnya perbankan syariah maupun non-perbankan syariah dimanajerial oleh orang-orang

\footnotetext{
${ }^{3}$ Haidar Putra Daulay, Pendidikan Islam dalam Sistem Pendidikan Nasional di Indonesia, (Jakarta: Kencana, 2012), cet ke-3,170

${ }^{4}$ Ideologi-ideologi yang dimaksud adalah kapitalisme, materialisme, naturalisme, pragmatisme liberalisme bahkan ateisme yang secara keseluruhan berpusat pada kesadaran manusia (anthrocentris). Berbeda dengan karakteristik keseimbangan ajaran Islam yang memadukan antara berpusat pada manusia (antrhopocentris) dan berpusat pada Tuhan (theocentris). Lihat Abuddin Nata, Kapita Selekta, (Jakarta: Rajagrafindo Persada), 13.

${ }^{5}$ Hermanto, Pengaruh Kualitas pelayanan DM bank Syariah Terhadap Keuasan Nasabah: Studi Pada BPRS Berkah Ramadhan, jurnal Etikonomi Vol. 12 No. 1 April 2013, 77
} 
muallaf "islamisasi orang yang sebelumnya berfikir kapitalis". Disinilah tugas dari PTAIN dan PTAIS untuk mencitpakan kader ekonomi rabbani yang mampu menjawab problematika tersebut dalam aspek syariah dan ekonomi meskipun hal ini tidak mudah.

Ditengah arus digitalisasi kehidupan, sektor ekonomi merupakan salah satu instrumen yang terkontaminasi dengan sendirinya terhadap perubahan tersebut. Seperti sirkulasi ekonomi masyarakat, transaksi lembaga keuangan bank dan non perbankan hingga arus perekonomian skala makro. Sumber daya manusia, digitalisasi sarana prasarana dan digitalisasi sistem mengarah kepada nilai positif.

Selain itu, ekonomi islam yang dikemas dengan beberapa bentuk transaksi keuangan islam semakin bertambah dengan sistem dan aplikasi tekhnologi yang lebih modern, efektif dan efesien. Diantara beberapa kemajuan tersebut seperti fintech, pasar modal, pasar uang, perusahaan start up dan filantropi islam (zakat, wakaf, infaq dan sadaqoh) dimana instrument tersebut beralih kepada tranksasi ecommerce, e-business, $e$ banking, e-payment, e-marketing dan e-learning. Semua dari instrument kewangan islam ini sudah dikemas dengan sistem dan aplikasi yang bertekhnologi canggih.

Banyak perusahaan pemerintah dan swasta yang memperluas layanan tersebut dengan sertifikat hak usaha dari Otoritas Jasa Keuangan (OJK).Peluang mempermudah mengurangi kemiskinan menggunakan inkubasi keuangan syariah di atas semakin meluas seiring minat dan usaha masyarakat dengan dunia tekhnologi. Dalam ranah implementasi sosial budaya ekonomi islam mengembangkan berbagai macam kelestarian dan pariwisata halal (halal tourism), makanan halal (halal food), penginapan syariah (hotel syariah) dan rumah sakit syariah. Di Indonesia khususnya wisata syariah sudah menjadi trend wisata remaja jaman milenial sebagai destinasi akhir pekan dan holiday.

Tumbuhnya lembaga keuangan syariah dan pelayanan berbasis syariah di dunia dan khususnya di Indonesia memberikan peluang kepada perguruan tinggi islam swasta dan perguruan tinggi islam negeri untuk memperluas program studi (jurusan) guna menyiapkan sumber daya yang di perlukan oleh pasar global di multidimensi. Hal ini selain dipengaruhi oleh ghiroh dalam kajian ekonomi islam secara ilmiah juga di dorong oleh kebutuhan pasar yang berpotensi kepada semakin meluasnya pangsa pasar (market share) ekonomi syariah di dunia. Secara kelembagaan, PTAI menunjukkan dua tren kelembagaan pembelajaran ekonomi Islam yang diselenggarakannya. Pertama, 
pembentukan jurusan/progran studi/konsentrasi yang mengusung secara spesifik ekonomi syariah. Kedua, pembentukan perguruan tinggi (sekolah tinggi) yang mengkhususkan diri pada studi ekonomi syariah. ${ }^{6}$

Di negara yang bukan mayoritas muslim seperti inggris telah membuka program jurusan yang konsentrasi kepada keuangan islam (Islamic finance) seperti louborugh university dan university of durhem dimana keduanya merupakan perguruan tinggi bergengsi di Inggris. Adapun London school of economics dan Harvard school of law sering mengundang pakar ekonomi islam komtemporer seperti Dr. Khursid Ahmad, Dr. Umar Chapra dan Prof. Abd. Mannan.

Keberadaan ekonomi islam yang telah diedukasi dan diimplementasikan di seluruh dunia membuktikan bahwa bukan hanya sekedar kewajiban bermuamalah secara syariah tetapi juga sebuah solusi untuk mencapai sebuah kesejahateraan dan keberlangsungan kehidupan yang layak sebagaimana telah dikembangkan di perguruan tinggi negeri mapupun swasta dan diperluas dengan inkubasi keuangan syariah saat ini.

\section{Analisis Strategi Di Zaman Digital}

\section{Manajemen Pendidikan Islam}

Langkah strategis dalam mengembangkan dan mempertahankan esensi manajemen pendidikan islam dengan mengunguli berbagai bidang untuk menjawab keperluan dan tantangan zaman. Langkah stategis tersebut harus dipersiapkan oleh lembaga pendidikan khususnya pendidikan tinggi islam dan swasta. Manajemen pengelolaan lembaga yang selama ini bersifat otoriter dan non komunikatif segera direvitalisasi dengan inovasi untuk keberlangsungan lembaga pendidikan.

Abuddin Nata menjelaskan bahwa pendidikan Islam membutuhkan SDM yang handal, memiliki komitmen dan etos kerja yang tinggi, manajemen yang berbasis sistem dan infrastruktur yang kuat, sumber dana yang memadai, kemauan politik yang kuat, serta standar yang unggul. ${ }^{7}$ Dunia pendidikan harus tanggap terhadap era digital yang dimunculkan dengan sistem berbasis internet dalam manajerialnya. Maka dari itu seharusnya lembaga pendidikan perguruan tinggi dengan mengoptimalkan media internet untuk menunjang sinergitas dan integritas pendidikan sebagaimana perguruan

\footnotetext{
6 Syaparuddin, Rekonstruksi Pembelajaran Ekonomi Islam Pada Perguruan Tinggi Agama Islam (Antisipasi Pengembangan Ke Depan), Jurnal At-Taradhi, Vol 3 No:1, Juni 2012, 15

Abuddin Nata, Kapita Selekta, (Jakarta: Rajagrafindo Persada), 18
} 
tinggi sebagai centre pencetak sumber daya yang siap pakai. Selain strategi ditas ada beberapa strategi yang dapat diimplementasikan oleh perguruan tinggi dengan target capaian optimal diantaranya adalah:

1. Peningkatan relasi dan kerjasama antar pedidikan tinggi nasional dan internasional. Strategi ini selain meningkatkan kwalitas perguruan tinggi dalam aspek manajerial juga dapat meningkatkan daya saing stake holder maupun mahasiswa dengan dunia global. Kemudian dapat berkolaborasi dalam peningkatan penelitian guna memberikan kontribusi kepada pengembangan ilmu pengetahuan.

2. Sinergitas kurikulum pendidikan tinggi Islam terpadu. Di dalam UU Sisdiknas dinyatakan bahwa pendidikan adalah usaha sadar dan terencana untuk mewujudkan suasana belajar dan proses pembelajaran agar peserta didik secara aktif mengembangkan potensi dirinya untuk memiliki kekuatan spiritual keagamaan, pengendalian diri, kepribadian, kecerdasan, akhlak mulia, serta keterampilan yang diperlukan dirinya, masyarakat, bangsa dan negara. ${ }^{8}$ Penjelasan Undang-undang Sistem Pendidikan Nasional Nomor 20 tahun 2003 pada bagian konsideran dijelaskan bahwa pentingnya dilakukan pembaharuan pendidikan secara terencana, terarah, dan berkesiambungan, dan salah satu strategi pembangunan pendidikan nasional ini adalah pengembangan dan pelaksanaan kurikulum berbasisi kompetensi. ${ }^{9}$

3. Standarisasi kepada Manajemen mutu International. Manajemen dalam implementasinya bukanlah tujuan tetapi instrument atau cara untuk mencapai mutu dan meningkatkan performance. Dalam strategi ini menuntut perguruan tinggi swasta dan negeri ntuk mengikuti standarisasi sistem manajemen yang telah dirumuskan oleh lembaga penjamin mutu international salah satunya seperti ISO, Six Sigma, Malcolm Baldrige, Sigapur Quality Award, Australian Quality Award, JAS (Japanese Agricultural Standard), BS (British Standard), IHPA (International Hardword Product Asociation), SNI (Standar Nasional Indonesia) dan IPS (Indonesian Plywood Standard).

\footnotetext{
${ }^{8}$ Burhan Nurgiantoro, Teori Pengkajian Fiksi, (Yogyakarta: Gajah Mada University Press, 1995), 282.

${ }^{9}$ Imam Mahalli dan Ara Hidayat, The Handbook of Education Management: teori dan Praktek Pengelolaan Sekolah/Madrasah di Indonesia, (Magister Pendidikan Islam UIN SUnan Kalijaga Yogyakarta), 603
} 


\section{Ekonomi Syariah}

Transaksi e-commerce, e-business, e-banking, e-payment, e-marketing, elearningdan digital marketing bukti dari majunya perekonomian berbasis digital yang berpengaruh kepada tingkat pembelian dan penjualan dan berpotensi besar terhadappertumbuhan ekonomi digital Indonesia. Apabila melihat nomenklatur perguruan tinggi secara khusus belum memberikan materi kuliah yang terkait dengan beberapa pelayanan internet diatas. Sehingga bisa dikongklusikan bahwa selama ini perguruan tinggi mencetak sumber daya manusia yang siap kerja tanpa mempersiapkan materi kuliah studi pembelajarannya kepada premis yang dibutuhkan di era digital ini. Bahkan membuka dan mengembangkan konsentrasi (jurusan) perguruan tinggi yang banyak dibutuhkan di zaman milenial. Dari beberapa literature yang dijadikan rujukan utama penulis menganalisis beberapa strategi yang harus dipersiapkan oleh perguruan tinggi islam negeri maupun swasta untuk bisa berdaya saing yang unggul antaranya sebagai berikut:

1. Membuka jurusan baru khusus digital marketing seperti: jurusan marketing digital syariah, pariwisata syariah, ${ }^{10}$ Bisnis Digital, ${ }^{11}$ dan Bisnis Manajemen Islam. $^{12}$

2. Peningkatan knowledge berbasis digital dengan memberikan ruang kepada mahasiswa dan fasilitas untuk mengakses dunia digital.

3. Meningkatkan kolaborasi dengan perusahaan nasional dan multinasional untuk memberikan peluang kerja.

Faisal Basri menganalisis kondisi perekonomian digital judul "Peta Perekonomian Indonesia Memasuki Era Digital" dengan mempersiapkan Top 7 Skill: ${ }^{13}$

1. Complex Problem Solving, ketika Negara melalui pemanfaatan teknologi mampu merubah khayalan dan impian manusia menjadi sebuah inovasi dengan menghasilkan banyak ragam dan system operasi produk barang dan jasa yang kompleks, maka hal itu akan meningkatkan globalisasi dan kemajuan teknologi,

\footnotetext{
${ }^{10}$ Seperti IAIN Bukit tinggi yang membuka jurusan pariwisata syariah.

${ }^{11}$ Universitas Padjajaran Bandung telah membuka jurusan bisnis digital, lihat E- Newsletter Universitas Padjadjaran, GENTRA, Edisi 3, Sabtu 17 Februari 2018, 1

${ }^{12}$ STEI Tazkia telah membuka jurusan Bisnis dan Manajemen Islam

${ }^{13}$ https://ristekdikti.go.id/persaingan-di-era-globalisasi-dan-ekonomi-digital/, diakses 26 Mei 2018
} 
berdampak pada banyaknya masalah yang akan dihadapi. Karena itu teknologi selalu merujuk pada sebuah "pertimbangan" melalui penerapan pengetahuan tentang sistem kompleks yang berkaitan dengan struktur dan system dinamik (Funke, 2001). Teknologi juga dimanfaatkan untuk membuat prediksi di lingkungan yang kompleks dengan cara melakukan penelitian dan kajian serta expert judgment dari “domain" pengetahuan tertentu,

2. Critical Thinking, bagaimana tingkat pendapatan global dapat berdampak nyata bagi kualitas hidup populasi masyarakat dunia. Teknologi menghasilkan harga murah dengan keuntungan jangka panjang dalam efisiensi dan produktivitas. Dengan teknologi, biaya transportasi dan komunikasi akan menurun, logistik dan rantai pasokan global lebih efektif, dan biaya perdagangan akan berkurang, yang itu semua akan membuka pasar baru dan mendorong pertumbuhan ekonomi. Hal tersebut merupakan pencerminan pemikiran kritis dari sebuah proses intelektualitas aktif dan terampil dalam mengkonseptualisasikan, menerapkan, menganalisis, mensintesis, yang dihasilkan secara cepat menggunakan pengamatan, pengalaman, refleksi, penalaran, atau komunikasi, sebagai panduan untuk keyakinan dalam tindakan. Secara umum, ini didasarkan pada nilai intelektual universal yang melampaui pembagian materi pelajaran: kejelasan, akurasi, presisi, konsistensi, relevansi, bukti yang baik, alasan bagus, kedalaman, keluasan, dan keadilan.

3. Creativity, yaitu meningkatnya capaian ketika pelaku kebijakan berhasil mengurangi ketegangan sosial. Dalam hal itu, teknologi merupakan salah satu alasan utama mengapa pendapatan mengalami stagnasi, atau bahkan menurun bagi sebagian besar penduduk di negara-negara berpenghasilan tinggi. Teknologi mengakibatkan permintaan akan pekerja terampil meningkat sementara permintaan pekerja dengan pendidikan rendah menurun.

4. People Management, ini menegaskan pada konteks seseorang yang mampu mengarahkan pada hasil kuat dan berkelanjutan dengan cara meningkatkan keterlibatan sumber daya manusia yang bekerja untuk mereka. Sehingga berdampak langsung pada bottom-line.

5. Coordinating with Other, teknologi di-era globalisasi begitu krusial, sehingga membutuhkan "perpanjangan tangan" yang efektif untuk meningkatkan skala keuntungan ekonomi. Karena itu dibutuhkan keterampilan berkoordinasi yang 
mencakup kapasitas untuk mengatur, dan menghubungkannya dengan keseluruhan alur kerja mencakup penanganan krisis, rintangan atau interupsi yang tak terduga.

6. Emotional Intelelligence, digitalisasi memiliki kemampuan untuk memacu setiap informasi yang diterima oleh masyarakat, sehingga setiap orang bisa mendapatkan "banjir informasi", baik yang bersifat lokal-regional dan internasional, di satu sisi bisa membuat manusia mendapatkan informasi yang diperlukan, tapi di lain pihak menjadi beban berlebih atas seluruh proses informasi yang diterima oleh setiap manusia atau masyarakat, sehingga dibutuhkan kecerdasan emosional yang mengidentifikasi dan mengelola tingkat emosional orang lain.

7. JudgementandDecissionMaking, keputusan yang baik membutuhkan tujuan yang jelas, spesifik, terukur, disepakati, realistis dan memiliki ketergantungan waktu.

\section{Tren Pembelajaran Digital}

Era globalisasi beberapa tahun terakhir sudah beralih kepada era digitalisasi yang ditandai dengan perubahan sistem yang serba cepat dan canggih. Sebagai contoh adalah perkembangan teknologi dalam hal ini teknologi komunikasi, yang menyebabkan masyarakat semakin gampang mendapatkan dan bertukar informasi. Konsekuensi perkembangan ini adalah pada saatnya nanti mereka yang ingin mendapatkan ilmu bisa memperolehnya tanpa kehadiran secara fisik di ruang kelas. ${ }^{14}$ Internet dapat dijadikan sebagai media alternatif untuk memberikan materi belajar (kuliah/sekolah) secara online. Sehingga materi belajar dapat diakses oleh siapapun yang membutuhkan, baik kelas dominan maupun kelas populer. Hal ini sangat membantu bagi mereka yang terkendala ruang dan waktu. ${ }^{15}$

Dalam laporan Indonesian Digital Education and E-Learning Market Outlook to 2018-Rising Trend Of Blended To drive The Future Growth menyatakan" "Lembaga pendidikan terkenal terkemuka di negara ini telah menjadi lebih reseptif terhadap penerapan komponen pembelajaran hi-tech. kemajuan kemajuan tekhnologi dibidang

\footnotetext{
${ }^{14}$ Mailing Oey-Gardiner Dkk, Era Disrupsi Peluang dan Tantangan Pendidikan Tinggi Indonesia, CetIII, ( Akademi Ilmu Pengetahuan Indonesia (AIPI)) 2017, 45

${ }^{15}$ Ginanjar Rahmat, "Masa Depan Pendidikan Bernama E-Leraning," dalam Nur Janti, dkk, Online! Geliat Manusia dalam Semesta Maya, cet ke-1, (Yogyakarta: EKSPRESI Buku LPM EKSPRESI, 2014), 120-121.

${ }^{16}$ Laporan Indonesian Digital Education and E-Learning Market Outlook to 2018-Rising Trend Of Blended To drive The Future Growth
} 
pendidikan di Indonesia telah memberikan sejumlah manfaatvbagi institusi pendidikan dan juga pelatih perusahaan seperti pelatihan multi-mdal, tas online dan tutorial, video streaming langsung dengan fakultas pengajaran dan beberapa fasilitas lainnya”.

Kondisi tersebut menuntut kepada perubahan-perubahan yang lebih efektif dan efesien dalam aspek pembelajaran dengan mengarah kepada pembelajaran based on digital. Pembelajaran digital dalam hal ini adalah menggunakan perangkat pembelajaran yang telah menggunakan tekhnologi canggih era milinial dan direlevansikan dengan perkembangan zaman yang selalu update. Seperti media pembelajaran, penyediaan layanan praktikum dan metode pebelajaran yang seluruhnya dengan tekhnologi. Penggunaan pembelajaran berbasis digital yang disebut e-learning faktanya sudah beberapa tahun yang lalu yang semakin berkembang dari masa ke masa seiring perkembangan tekhnologi dan komputerisasi.

E-learning telah diperkenalkan oleh universitas Illinois di Urbana-Champaign dengan sistem computer-assisted instruction dan computer bernama plato. Kemudian di era CBT (Computer Based Training) muncullah aplikasi-aplikasi e-learning yang dioperasionalkan dalam bentuk PC Standalone yang materinya berbentuk tulisan atau media.Seiring semakin berkembangnya CBT (computer based test CBT) semakin banyak produk e-learning yang ditawarkan salah sataunya LMS (learning management system) yang dikeluarkan oleh AICC (Airline Industry CBT Commette), IMS, ARIADNE dan sebagainya dan berkembanga kepada aplikasi e-learning berbasis web pada awal tahun 2000-an. Kemuidan di era digitlisasi ini Menristekdikti menargetkan perkuliahan daring atau e-learningdi perguruan tinggi akan diselenggarakan mulai tahun 2018. Seperti online learning atau daring diselenggarakan dimana peserta didik dapat mengakses materi, berinteraksi dengan materi, pengajar dan pembelajaran lain serta mengembangkan keilmuannya melalui pengalaman belajar.

E-learning memberikan kemudahan mengakses informasi dan kolaborasi untuk membangun budaya belajar kepada peserta didik dengan media selular, sosial, cloud, big data, virtual reality maupun augmented reality dan komunikasi terpadu dengan mudah.Namun yang lebih penting dengan tren pembelajaran digital adalah pemilihan media dan mengatur parameter media pembelajaran yang digunakan karena dengan hal tersebut sinergitas dan kolaborasi pembelajaran digital bisa diaplikasikan.Karena banyak perguruan tinggi yang antusias untuk memanfaatkan solusi-solusi digital dalam 
rangka menudukung terwujudnya proses pembelajaran digital yang semakin interaktif dan terpadu ternyata terdapat kendala akibat kurangnya sumber daya pendukung. Kurangnya sumber daya pendukung pada dasarnya terdapat solusi karena inti dari pembelajaran digital adalah dengan internet based learning. Adapun perangkat dan aplikasi yang mendorong didalamnya dapat disinergikan antar perguruan tinggi yang dipandu oleh menristekdikti dan kemenag bagian pengelolaan perguruan tinggi.

\section{Digitalisasi Infrastruktur}

Dalam rangka meningkatkan kwalitas pendidikan untuk merespon era digitalisasi, pembenahan infrasturktur menjadi keharusan bagi perguruan tinggi utamanya insfrastuktur yang berbasis digital di zaman milenial ini. Karena pelayanan yang memadai dan difungsikan secara optimal juga mendorong dalam mencetak output yang berkwalitas yang didukung dengan kemudahan pelayanan. Pembenahan digitalisasi infrastruktur selain memudahkan pelayanan kepada mahasiswa juga akan meningkatkan rating akreditasi perguruan tinggi.

Dengan kondisi yang ada selama ini dimana belum terwujudnya infrastruktur atau sarana prasarana fisik maupun non fisik ${ }^{17}$ harus segera dibenahi dengan optimalisasi kreatifitas dan keberanian mencoba metode dan tekhnologi baru yang lebih efektif dan efesien.Sebagaimana selama ini optimasilasi media web sebagai information centre telah banyak digunakan di setap perguruan tinggi. Namun tidak hanya sebatas hal tersebut, spectrum layanan digital yang menunjang kepada perbaikan infrastruktur harus diciptakan dan diselenggarakan secepatnya. Meskipun dalam hal ini perguruan tinggi islam khsusnya swasta mempunyai kendala dalam aspek penyediaan layanan tersebut.

Digitalisasi infrastuktur yang selama ini yang terjadi dipengaruhi oleh tekhnologi cepat dan komunikasi tanggap mulai menggeliat dalam praksis pendidikan perguruan tinggi seperti perubahan dari face to face ke blanded learning atau online distance learning maupun big data. Akan tetapi revolusi pendidikan tinggi 4.0 bukan hanya sekedar digitalisasi pendidikan, karena perubahan instrumental tersebut niscaya terjadi disebabkan revolusi digital yang menuntut perubahan kepada semua aspek.

\footnotetext{
${ }^{17}$ Infrastuktur sering dimaksudkan menjadi sarana-prasarana teknologis yang berwujud fisik seperti perangkat keras, jaringan kabel, dan bangunan. Padahaninfrastruktur juga mencakup kepada berbagai hal non-fisik seperti struktur sosial-budaya, aspirasi masyarakat dan cara kerja.
} 
Kemajuan infrastruktur terutama gedung perkuliahan dan fasilitas mahasiswa secara prosentase seluruh perguruan tinggi di Indonesia memang berubah. Tetapi kultur belajar dan pembelajaran mapun mandset berfikir penggeliat pendidikan dan peserta didik tak beranjak dari tradisi peluhuan tahun sebelumnya. Ini adalah sebuah celah yang harus diperbaiki oleh semua elemen pendidikan meskipun didukung dengan perubahan infrasturktur based ondigitial. Karena ekspektasi dalam perubahan ini yaitu perubahan secara hakiki dengan digitalisasi era dalam semua lini adakalanya infratruktur fisik dan non fisik.

\section{Rekonstruksi Pembelajaran Manajemen Pendidikan Islam dan Ekonomi Syariah}

Pembelajaran Manajemen pendidikan islam di perguruan tinggi islam swasta dan perguruan tinggi islam negeri di Indonesia akhir-akhir ini semakin meningkat. Animo masyarakat untuk meningkatkan kualitas pengelolaan lembaga pendidikan dan dorongan dari pemerintah dalam mencetak generasi yang unggul dengan kemampuan edukasi yang komplet dengan iptek dan imtaq nya membuat PTAIS maupun PTAIN memperluas konsentrasi pembelajaran akademiknya dengan mengembangkan aspek pendidikan islam dalam pengelolaan (manajemen).

Dalam memperluas program studi yang diedukasikan maka merekonstruksi pembelajaran sebagai sebuah proses untuk mencapai pada pendidikan optimal sebagaimana tujuan utama pendidikan. Metodologi pembelajaran yang selama ini berkarakter dogmatis-doktriner dan tradisional menuju kepada pembelajaran yang dinamis-aktul dan konstekstual. ${ }^{18}$ Hal ini diupayakan agar pendidikan agama islam dan ekonomi syariah yang selama ini dijalankan ceat beradaptasi dengan sistem pembelajaran yang respek terhadap aktualisasi kehidupan yang terjadi dengan pendekatan-pendekatan digital.

Jurusan manajemen, sejak beberapa tahun terakhir telah memperluas jurusan/program studi kepada manajemen pendidikan islam di perguruan tinggi negeri maupun swasta. Hal tersebut dalam memberikan wawasan yang lebih mendalam kepada

\footnotetext{
${ }^{18}$ Menurut Dirkx, Amey, and Haston bahwa pembelajaran denganpendekatan kontekstual bersumber dari pendekatan konstruktivis. Lihat, Dirkx, J. M.; Amey, M.; and Haston, L., "Context in the Contextualized Curriculum:Adult Life Worlds as Unitary or Multiplistic?” In Proceedings of the 18th Annual Midwest reserach to Practice Conference in Adult, Continuing, and Community Education,edited by A. Austin, G. E. Nynes, and R. T. Miller, (St. Louis: University of Missouri atSt. Louis, 1999), 79-84.
} 
masyarakat khususnya pengelola (praktisi) pendidikan islam bahwa sistem yang telah ada selama ini senantiasa berkembang dan maju dengan pengelolaan yang modern sehingga dapat mencetak lulusan sekolah/madrasah/perguruan tinggi yang dapat mengelola pendidikan dengan prinsip dan sistem pendidikan islam yang baik. Pembangunan bidang pendidikanmempunyaiperan strategis sebagai salah satu faktor terwujudnya kehandalan Sumber Daya Manusia (SDM). ${ }^{19}$ yang diperlukan sebagai salah satu modal dasar kesinambungan pembangunan nasional. ${ }^{20}$

Secara kelembagaan PTAIS dan PTAIN menunjukkan dua trend pembelajaran ekonomi yang diselengarakan. ${ }^{21}$ Pertama, selain terdapat perbedaan nomenklatur jurusan, terdapat pula variasi nomenklatur fakultas yang menaungi jurusan tersebut, yaitu terdapat tiga fakultas: (1) fakultas syariah, (2) fakultas syariah dan hukum atau fakultas syariah dan ilmu hukum, dan (3) fakultas ekonomi atau fakultas ekonomi dan binis. Kedua, pembentukan perguruan tinggi (sekolah tinggi) yang mengkhususkan diri pada studi ekonomi Islam/syariah, pembelajaran ekonomi Islam diselenggarakan oleh jurusan/ program studi/konsentrasi yang juga berbeda satu sama lain.

Melihat perubahan dan perluasan konsentrasi yang diajarkan dan mengikut perkembangan industrialisasi digital maka menristekdikti menjelaskan ada lima elemen penting yang menjadi perhatian dan dilaksanakan untuk mendorong pertumbuhan ekonomi dan daya saing bangsa di era Revolusi Industri 4.0, yaitu: ${ }^{22}$

1. Persiapan sistem pembelajaran yang lebih inovatif di perguruan tinggi seperti penyesuaian kurikulum pembelajaran, dan meningkatkan kemampuan mahasiswa dalam hal data Information Technology (IT), Operational Technology (OT), Internet of Things (IoT), dan Big Data Analitic, mengintegrasikan objek fisik, digital dan manusia untuk menghasilkan lulusan perguruan tinggi yang kompetitif dan terampil terutama dalam aspek data literacy, technological literacy and human literacy.

2. Rekonstruksi kebijakan kelembagaan pendidikan tinggi yang adaptif dan responsif terhadap revolusi industri 4.0 dalam mengembangkan transdisiplin ilmu dan program

\footnotetext{
${ }^{19}$ M. Enoch Markum, Pendidikan Tinggi dalam PerspektifSejarah dan Perkembangannya di Indonesia, (Jakarta: PenerbitUniversitas Indonesia 2007), 4-5.

${ }^{20}$ Djohar, Pengembangan Pendidikan NasionalMenyongsong Masa Depan. (Yogyakarta: Grafika Indah, 2006), 5

${ }^{21}$ Syaparuddin, Rekonstruksi Pembelajaran Ekonomi Islam Pada Perguruan Tinggi Agama Islam (Antisipasi Pengembangan ke Depan), Journal At-Taradhi , Vol 3, No 1 (2012),.15

${ }^{22} \mathrm{https}: / /$ www.ristekdikti.go.id/pengembangan-iptek-dan-pendidikan-tinggi-di-era-revolusi-industri-4-0-2/ diakses 27 Mei 2018.
} 
studi yang dibutuhkan. Selain itu, mulai diupayakannya program Cyber University, seperti sistem perkuliahan distance learning, sehingga mengurangi intensitas pertemuan dosen dan mahasiswa. Cyber University ini nantinya diharapkan menjadi solusi bagi anak bangsa di pelosok daerah untuk menjangkau pendidikan tinggi yang berkualitas.

3. Persiapan sumber daya manusia khususnya dosen dan peneliti serta perekayasa yang responsive, adaptif dan handal untuk menghadapi revolusi industri 4.0. Selain itu, peremajaan sarana prasarana dan pembangunan infrastruktur pendidikan, riset, dan inovasi juga perlu dilakukan untuk menopang kualitas pendidikan, riset, dan inovasi.

4. Terobosan dalam riset dan pengembangan yang mendukung Revolusi Industri dan ekosistem riset dan pengembangan untuk meningkatkan kualitas dan kuantitas riset dan pengembangan di Perguruan Tinggi, Lembaga Litbang, LPNK, Industri, dan Masyarakat.

5. Terobosan inovasi dan perkuatan sistem inovasi untuk meningkatkan produktivitas industri dan meningkatkan perusahaan pemula berbasis teknologi.

Dengan semangat inovasi dan pergerakan perubahan yang dilakukan kemenristekdikti dalam upaya meningkatkan daya saing perguruan tinggi diatas merupakan revolusi industry yang tidak dapat dihindari disebabkan digitalisasi era dengan ditandai penerapan tekhnologi online dan digital yang menuntut kecepatan dan ketepatan manajerial dalam aspek kelembagaan dan pembelajaran secara keseluruhan.

\section{Kesimpulan}

Era digitalisasi memberikan dampak yang signifikan kepada perubahan pendidikan-sosial-budaya-dan politik. Perubahan-perubahan tersebut sebagai kehidupan baru yang menjamin keberlangsungan hidup yang mebutuhkan kepada berbagai aspek instrument dan sistem yang telah dibentuk. Manajemen Pendidikan Islam dan Ekonomi islam adalah sebuah proses keilmuan yang akan membentuk peradaban dan sistem yang kongkrit untuk mencetak out put multidimensi sesuai perkembangan zaman. Peluang, tantangan, strategi dan inovasi harus dilakukan oleh perguruan tinggi islam swasta dan negeri sebagai upaya mencapai orientasi dari penciptaan makhluk sebagai khalifah di bumi. 
Kongklusi dari uraian tulisan ini dimana e-learning, e-management, e-transaction dan pengelolaan berbasis internet lainnya adalah solusi solutif sebagai proses berjalannya lembaga pendidikan islam dengan kemudahan pelayanan yang diproduksikan. Kemajuan tekhnologi dan informasi telah dimanfaat oleh perguruan tinggi dalam aspek strategi digitalisasi pembelajaran, digitalisasi infrastruktur, admintrasi berbasis digital dan perubahan budaya lokal menuju budaya internasional based on digital yang bermanfaat. Berbagai inovasi pendidikan tinggi berbasis digital telah mampu menciptakan output yang multidimensi khususnya perguruan tinggi islam negeri dan swasta. keinginan menuju perubahan yang baik telah diupayakan oleh semua perguruan tinggi negeri maupun swasta yang mengoptimalkan media tekhnologi dan informasi dengan semua perangkat pendukungnya. Sinergitas dan integritas perguruan tinggi islam sebagai wadah pendidikan lanjutan diharapkan mampu bersaing dengan tanpa menghilangkan ruh maupun nilai-nilai keislaman. 


\section{Daftar Pustaka}

Arifi, Muhammad. 2010. Politik Pendidikan Islam: Menelusuri Ideologi dan Aktualisasi Pendidikan Islam di Tengah Arus Globalisasi. Cet-1, Yogyakarta: Penerbit teras.

Dirkx, J. M.; Amey, M.; and Haston, L. 1999. "Context in the Contextualized Curriculum: Adult Life Worlds as Unitary or Multiplistic?" In Proceedings of the 18th Annual Midwest reserach to Practice Conference in Adult, Continuing, and Community Education, edited by A. Austin, G. E. Nynes, and R. T. Miller. St. Louis: University of Missouri at St. Louis.

Djohar. 2006. Pengembangan Pendidikan Nasional Menyongsong Masa Depan. Yogyakarta: Grafika Indah.

Daulay, Putra, Haidar. 2012. Pendidikan Islam dalam Sistem Pendidikan Nasional di Indonesia. Cet-3. Jakarta: Kencana.

E- Newsletter Universitas Padjadjaran. GENTRA. Edisi 3. Sabtu 17 Februari 2018.

Nata, Abuddin. 2004. Kapita Selekta. Jakarta: Rajagrafindo Persada.

Mahalli, Imam dan Hidayat, Ara. The Handbook of Education Management: teori dan Praktek Pengelolaan Sekolah/Madrasah di Indonesia. Magister Pendidikan Islam UIN Sunan Kalijaga Yogyakarta.

Markum, Enoch, M. 2017. Pendidikan Tinggi dalam PerspektifSejarah dan Perkembangannya di Indonesia. Jakarta: Penerbit Universitas Indonesia.

Nurgiantoro, Burhan. 1995. Teori Pengkajian Fiksi. Yogyakarta: Gajah Mada University Press.

Rahmat, Ginanjar. 2014. “Masa Depan Pendidikan Bernama E-Leraning,” dalam Nur Janti, dkk. Online! Geliat Manusia dalam Semesta Maya, cet ke-1. Yogyakarta: Ekspresi Buku Lpm Ekspresi, 2014.

Salim, Emil, dkk. 1997, Manajemen dalam Era Globalisasi, Jakarta: PT. Elex Media Komputindo. 
Syaparuddin, "Rekonstruksi Pembelajaran Ekonomi Islam Pada Perguruan Tinggi Agama Islam: Antisipasi Pengembangan Ke Depan":, Jurnal At-Taradhi, Vol 3 No:1, Juni 2012.

Tjiptino, Fandy dan Santoso, Budi, Totok. 2010. Strategi Riset Lewat Internet. Yogyakarta: Andi.

Oey-Gardiner, Mailing Dkk. 2017. Era Disrupsi Peluang dan Tantangan Pendidikan Tinggi Indonesia, Cet-3. Akademi Ilmu Pengetahuan Indonesia (AIPI).

https://ristekdikti.go.id/persaingan-di-era-globalisasi-dan-ekonomi-digital/, diakses 26 Mei 2018.

https://www.ristekdikti.go.id/pengembangan-iptek-dan-pendidikan-tinggi-di-erarevolusi-industri-4-0-2/ diakses 27 Mei 2018. 